
Michigan

MiChAEL J. WYNNE

\title{
The transfer of Gelidiella trinitatensis W.R.TAYLOR (Gelidiales, Rhodophyta) to Parviphycus
}

\author{
With 4 Figures
}

Keywords: Carribean, Gelidiellae trinitatensis, marine algae, Parviphycus trinitatensis

\begin{abstract}
Evidence is presented to support the transfer of the red algal species Gelidiella trinitatensis W. R. TAYLOR (Gelidiales) to the segregate genus Parviphycus SANTEL. The very small stature of this alga, the arrangement of tetrasporangia in distinct chevron rows, the organization as seen in transverse section, and the apical organization indicate its correct taxonomic placement is within the genus Parviphycus. This species, originally described from Trinidad in the southern Caribbean Sea, is now known to be widely occurring throughout the Caribbean. It has also been reported from Central and South America.
\end{abstract}

\section{Introduction}

Gelidiella was established by FELDMANN \& HAMEL (1934) as a new name to replace the illegitimate generic name Echinocaulon KÜTZING (1843), which was a later homonym. The type species was Gelidiella acerosa (FORSSK.) FELDMANN \& HAMEL, a species with a worldwide tropical distribution and of economic value because of its high agar content (GANZON-FORTES 1994). Over the years many species have been added to Gelidiella. Two categories of species were recognized within the genus, these two groups being separated by differences in their apical organization and in the manner in which tetrasporangia were arranged (RICO et al. 2002; SANTELICES 2002). The apical divisions in Gelidiella, as seen in G. acerosa, show a decussate pattern, the cell divisions of the subapical and subsequent cells in the axial filament occurring at right angles to each other (SANTELICES 2002). Thus, the central axial filament is discernible only a short distance below the branch apex (MELO 1992). On the other hand, the apical divisions in Parviphycus, as observed in P.adnatus and $P$. tenuissimus, show a lateral pattern. The axial cell cuts off 2-4 periaxial cells, which cut off further cells laterally (RICO et al. 2002). So the arrangement is more distichous than decussate (SANTELICES 2002). Some species, including the generitype of Gelidiella, produce tetrasporangia in a compact and random pattern in fertile axes, whereas other species produced tetrasporangia in cylindrical stichidia with the sporangia formed in regular transverse rows. The former group was called the "acerosatype", and the latter group was called the "pannosa-type" (GANZON-FORTES 1994). This distinction was pointed out by many authors (GUIRY \& WOMERSLEY 1992; KRAFT \& ABBOTT 1998; SANTELICES 2002). In a detailed study of $G$. acerosa and several other species then assigned to Gelidiella, SANTELICES (2004) presented arguments to recognize the segregate genus Parviphycus, with $P$. adnatus (E.Y.DAWSON) SANTEL. designated the generitype. Three additional species were transferred by SANTELICES (2004) to his new genus: P. antipae ["antipai'] (CELAN) SANTEl., P. tenuissimus (FELDMANN \& HAMEL) SANTEL., and P. womersleyanus (KRAFT \& I.A.ABBOTT) SANTEL. Subse- 
quently, AFONSO-CARRILLO et al. (2007) transferred Gelidiella setacea (FELDMANN) FELDMANN \& HAMEL into Parviphycus, and the new species $P$. felicinii was described by PERRONE $\&$ Delle Foglie (2006). Gelidiella and Parviphycus are the only two genera now assigned to the Gelidiellaceae (FAN 1961; PERRONE et al. 2006). Gelidiella trinitatensis W.R.TAYLOR (TAYLOR 1943) remains an incompletely studied species. The small stature of the plants in this species and the production of the sporangia in distinct chevrons were features that led HUISMAN et al. (2009) to suggest that G. trinitatensis had affinities with Parviphycus. But because they had not seen authentic material, they refrained from making a transfer.

\section{Materials and methods}

The Holotype of Gelidiella trinitatensis was first deposited in the personal herbarium of W. R. TAY LOR (TAYLOR 1943). That herbarium is now incorporated in the University of Michigan Herbarium $(\mathrm{MICH})$, Ann Arbor. The holotype of G. trinitatensis was examined in this study. Whole mounts were prepared, and cross-sections were made using a single-edge razor blade and mounted on glass slides for examination under a standard Zeiss research compound microscope. An EPSON Scan Ver. 1.28A (Seiko Epson Corp.) was used to capture an image of the holotype. Line-drawings of portions of the holotype were prepared using a camera-lucida mounted on the microscope. The software program Adobe Photoshop CS3 Version 10.0 was then used to prepare the art-work. Author abbreviations of taxa are in accordance with BRUMMITT \& POWELL (1992): http://www.ipni.org/ipni/query_author.html. Herbarium abbreviations are according to the on-line Index Herbariorum: http://sciweb.nybg.org/science2/ IndexHerbariorum.asp.

\section{Results}

Observations were made on the holotype, which consist of two small matted clusters of branched terete axes (Fig. 1). Axes are decumbent and give rise to erect axes that are sparingly and irregularly branched (Fig. 2). Vegetative axes are terete, $52-80(-100) \mu \mathrm{m}$ in diameter, ending in a single transversely dividing apical cell (Fig. $3 \mathrm{a}-\mathrm{c})$. The lateral pattern of division of the axial filament was of the Parviphycus type rather than the decussate pattern of Gelidiella. Cross-sections of erect axes show

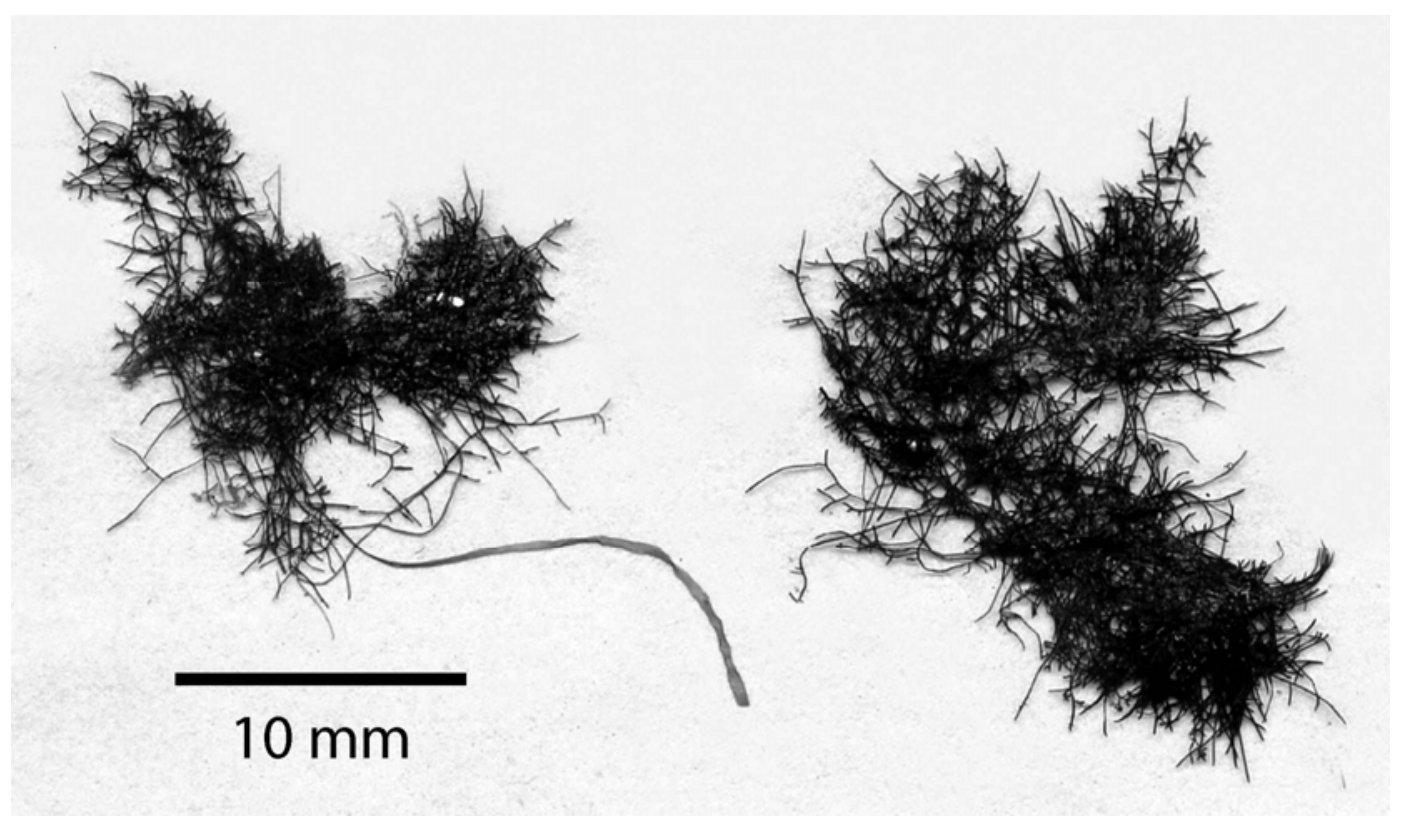

Fig. 1

Parviphycus trinitatensis. Holotype of Gelidiella trinitatensis in MICH. 


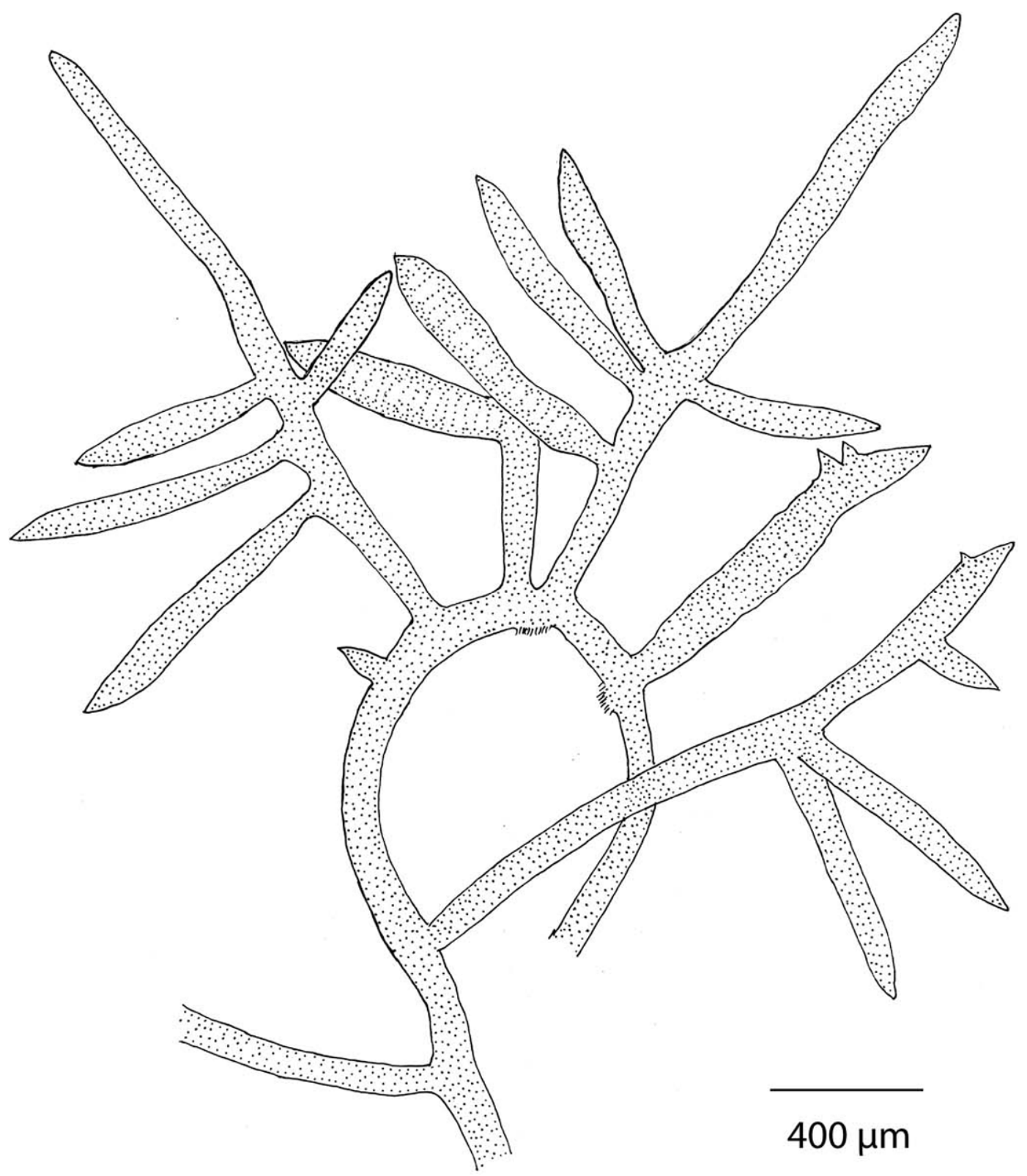

Fig. 2

Parviphycus trinitatensis. Habit

an absence of narrow rhizines (Fig. 3d). Tetrasporangial stichidial portions of axes are compressed to flattened, $98-162 \mu \mathrm{m}$ in width and $325-715 \mu \mathrm{m}$ in length (Fig. 4a, b). Usually only the distalmost portions of a stichidium still retain sporangia, the rest of the stichidium having shed the spores. Stichidia range from simple to bearing lateral secondary stichidia, thus pinnately branched. Tetrasporangia are arranged in chevrons, thus, the V-formation as described by TAYLOR (1943). The mature tetrasporangia are $22-25 \mu \mathrm{m}$ in diameter and 

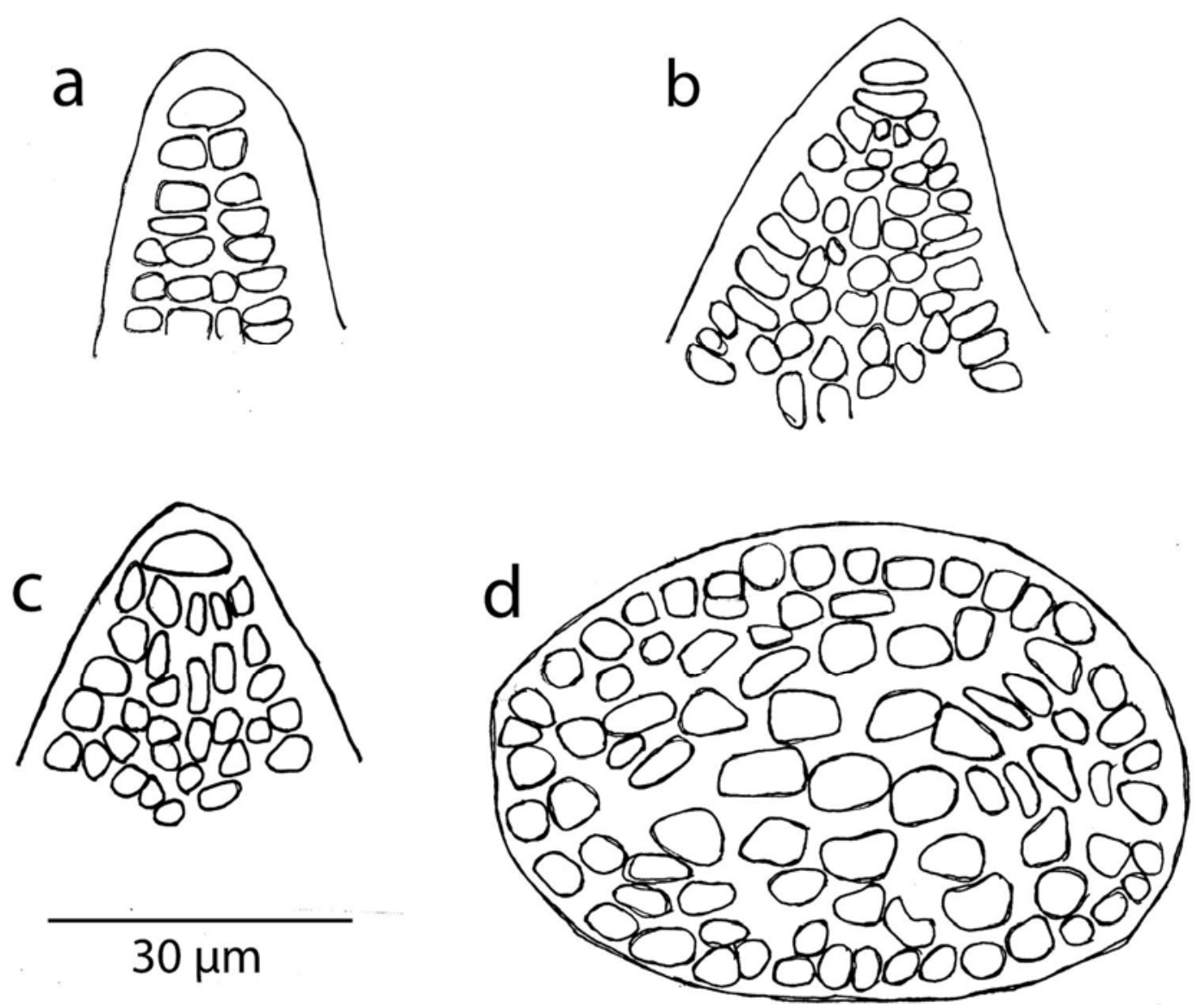

Fig. 3

Parviphycus trinitatensis

a-c - camera-lucida drawings of apices; $d$ - camera-lucida drawing of cross-section of axes

show irregular patterns of division, sometimes appearing cruciform and other times appearing to be tetrahedral.

\section{Discussion and conclusions}

When TAYLOR (1943) described Gelidella trinitatensis, he provided only a single figure, which was of the habit. TAYLOR described the plant as being minute and creeping, giving rise to erect portions usually only $2-10$ (rarely to 15) $\mathrm{mm}$ in height and segments to $100 \mu \mathrm{m}$ in diameter. He observed tetrasporangia to be produced in simple or pinnate to subpalmate branchlets and stressed the feature that the tetrasporangia originated in obvious $\mathrm{V}$-shaped rows near the apices. These rows later become obscured. The spores are released from the base of the stichidium as maturation of sporangia proceeds distally. The feature that TAYLOR (1943) regarded as distinguishing his new species from Gelidium crinale was the very regular arrangement of the tetrasporangia in "V-shaped rows" and the fact that these fertile branchlets "appeared stichidium-like". The features seen in the holotype of G. trinitatensis, including the apical pattern of division, are the characteristics of the segregate genus Parviphycus as stated by SANTELICES (2004). Therefore, the following transfer is proposed: 
a

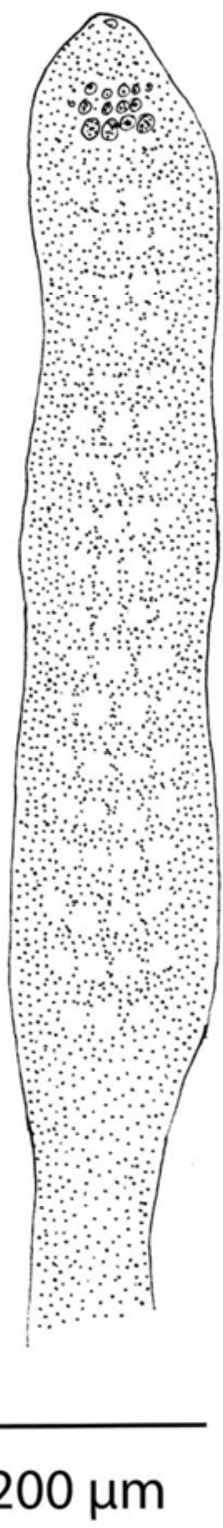

b

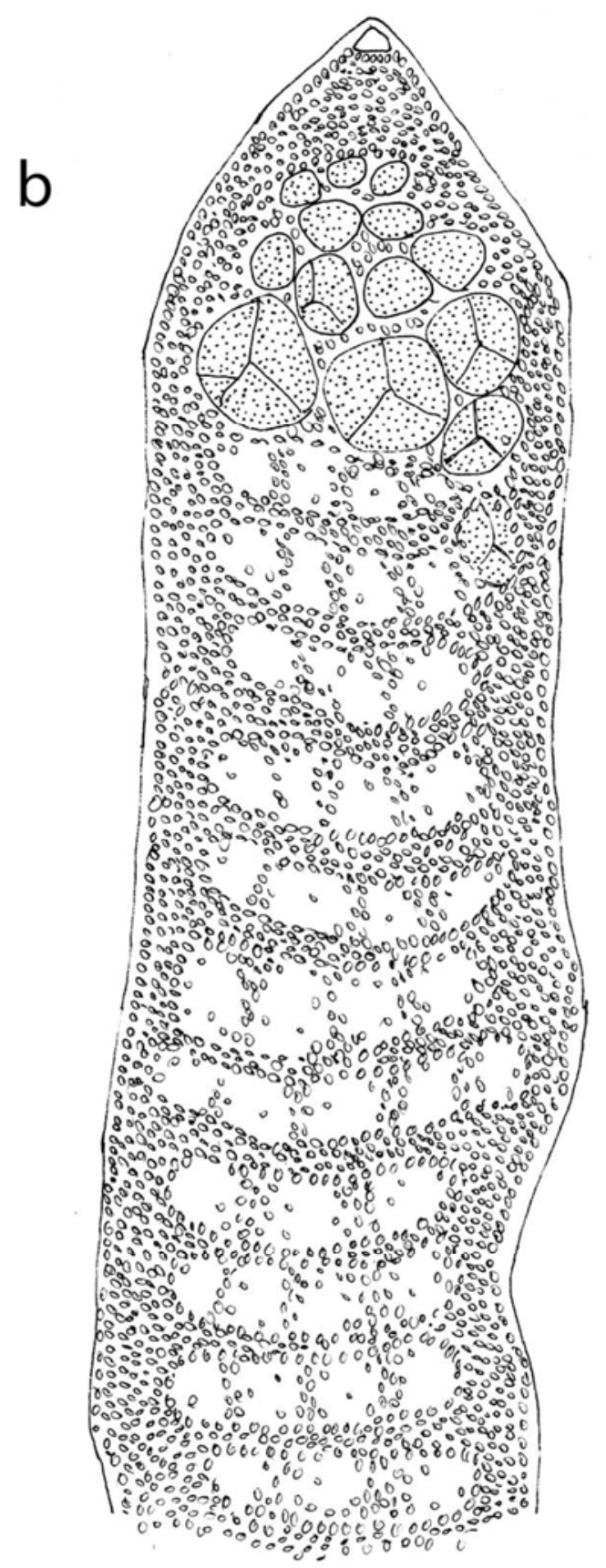

\section{$50 \mu \mathrm{m}$}

Fig. 4

Parviphycus trinitatensis

a, $b$ - camera-lucida drawings of tetrasporangial stichidia, from which spores have mostly been already shed 


\section{Parviphycus trinitatensis (W.R.TAYLOR)} M.J.WYNNE comb. nov.

Basionym: Gelidiella trinitatensis W.R.TAYLOR, Pap. Mich. Acad. Sci., Arts \& Lett. 28: 150, pl. I, fig. 1. (1943).

TAYLOR (1943) described Gelidiella trinitatensis with a type locality of Manzanilla Point, Trinidad, West Indies. The type material was collected by ROLAND THAXTER and had been earlier identified by TAYLOR (1929) as Gelidium crinale (TURNER) GAILLON. Subsequently, $G$. trinitatensis has been reported from the States of São Paulo (JOLY 1965) and Rio de Janeiro, Brazil (BRASILEIRO et al. 2009), Costa Rica (TAYLOR 1960), Grand Cayman Island (TAYLOR 1969), Quintana Roo and Vera Cruz, Mexico (GARZA BARRIENTOS 1976; MENDOZA-GONZÁLEZ \& MATEO-CID, 1985, 1992; ORTEGA et al. 2001), Venezuela (GANESAN 1990), Belize (LiTTLER \& LiTTLER 1997), Cuba (CABrera et al. 2004; SUÁreZ 2005), Pacific Panama (LITTLER \& LITTLER 2009), and generally throughout the Greater and Lesser Antilles, the Caribbean, and the Gulf of Mexico (LITTLER \& LITTLER 2000).

\section{Acknowledgements}

The author is grateful to Mr. John Cramer of PC Helps Support, LLC, Philadelphia, for his remote assistance in preparing the figures. The author has no commercial or financial conflicts of interest with the content of this article.

\section{References}

Afonso-Carrillo, J.; Sansón, M.; SAngril, C. \& DíAZ-VILLA, T. 2007: New records of benthic marine algae from the Canary Islands (eastern Atlantic Ocean): morphology, taxonomy and distribution. - Bot. Mar. 50: 119-127.

BRASILEIRO, P. S.; Yoneshigue-VAlentin, Y.; BAHIA, R. DA G.; ReIS, R. P. \& AMAdo FILHO, G. M. 2009: Algas marinhas bentónicas da região Cabo Frio e arredores: síntese do conhecimento. - Rodriguésia 60: 39-66.

BrummitT, R. K. \& Powell, C. E. (eds.) 1992: Authors of plant names. A list of authors of scientific names of plants, with recommended standard forms of their names including abbreviations. - Royal Bot. Gardens, Kew.

CABrera, R.; Moreira, A. \& SuAREZ, A. M. 2004: Variación en la composición y estructura de las asociaciones algales en la Bahía de Nuevitas, Costa NE de Cuba. - Rev. Invest. Mar. 25: 133 142.

FAN, K.-C. 1961: Morphological studies of the Gelidiales. - Univ. Calif. Publ., Bot. 32: 315368.

Feldmann, J. \& Hamel, G. 1934: Observations sur quelques Gélidialacées. - Rev. Gen. Bot. 46: 528-549.

GANeSAN, E. K. 1990 ["1989”]: A catalog of benthic marine algae and seagrasses of Venezuela. Fondo Editorial Conicit, Caracas.

GANZON-FORTES, E. T. 1994: Gelidiella: 149-184. In: I. AKATSUKA (ed.), Biology of economic algae. - The Hague.

GARZA-BARRIEnTos, M. A. 1976: Primaras consideraciones referentes a la flora marina del sureste de la República Mexicana: 210-239. - Memorias de la Primera Reunión Latinoamericana de Ciencias y Tecnologia Oceanográficas (México).

GUIRY, M. D. \& WOMERSLEY, H. B. S. 1992: Gelidiella minima sp. nov. (Rhodophyta) from Victoria, Australia: implications for the generic classification of the Gelidiaceae. - Br. Phycol. J. 27: $165-176$.

Huisman, J. M.; Phillips, J. C. \& Freshwater, D. W. 2009: Rediscovery of Gelidiella ramellosa (Kützing) Feldmann et Hamel (Gelidiales, Rhodophyta) from near the type locality in Western Australia. - Cryptog., Algol. 30: 3-10.

JoLY, A. B. 1965: Flora marinha do litoral norte do estado de Saõ Paulo e regiões circunvizinhas. Bolm. Fac. Fil Ciênc. Let. Univ. S. Paulo, Botânica 21: 5-393.

Kraft, G. T. \& Аввотt, I. A. 1998: Gelidiella womersleyana (Gelidiales, Rhodophyta), a diminutive new species from the Hawaiian Islands. Bot. Mar. 41: 51-61.

KützING, F. T. 1843: Phycologia generalis. Leipzig.

LitTLER, D. S. \& LitTleR, M. M. 1997: An illustrated flora of the Pelican Cays, Belize. Bull. Biol. Soc. Wash. 9: 1-149.

LitTleR, D. S. \& LitTleR, M. M. 2000: Caribbean reef plants. An identification guide to the reef plants of the Caribbean, Bahamas, Florida and Gulf of Mexico. - OffShore Graphics, Washington D.C.

LitTLER, D. S. \& LitTler, M. M.. 2009. Marine plants of Pacific Panama. - Smithsonian Tropical Research Institute, Smithsonian Institution. http://biogeodb.stri.si.edu/pacificalgae.

MELo, R. A. 1992: A note on the absence of hyphae (rhizines) in the thallus of Gelidiella acerosa Forsskål, Feldmann et Hamel (Rhodophyta): 173-181. - In: I. A. АввотT (ed.), Taxonomy of economic seaweeds with reference to some Pacific and western Atlantic species, Vol. III. - 
California Sea Grant College Program, La Jolla, California.

MendozA-González, A. C. \& Mateo-Cid, L. E. 1985: Contribución al conocimiento de la flora marina bentónica, de las Islas Sacrificios y Santiaguillo, Veracruz, México. - Phytologia 59: 9-16.

Mendoza-González, A. C. \& Mateo-Cid, L. E. 1992: Algas marinas bentónicas de Ilas Mujeres, Quintana Roo, México. - Acta Bot. Mex. 19: $37-61$.

Ortega, M. M.; Godínez, J. L. \& Solorzano, G. G. 2001: Catálogo de algas bénticas de las costas Mexicanas del Golfo de México y Mar Caribe. Cuadernos 34, Universidad Nacional Autónoma de México.

Perrone, C. \& Delle Foglie, C. I. 2006: Parviphycus felicinii sp. nov. (Gelidiales, Rhodophyta) from south-east Italy. - Cryptog., Algol. 27: 199-209.

Perrone, C.; Felicini, G. P. \& A. Bottalica, A 2006: The prostrate system of the Gelidiales: diagnostic and taxonomic importance. - Bot. Mar. 49: 23-33.

RICO, J. M.; FrESHWATER, D. W.; NORWOOD, K. G. \& GuIRY, M. D. 2002: Morphology and systematics of Gelidiella tenuissima (Gelidiales, Rhodophyta) from Gran Canaria (Canary Islands, Spain). - Phycologia 41: 463-469.

SANTELICES, B. 2002: The taxonomic status of Gelidiella adnata (Gelidiales, Rhodophyta): 151166. - In: I. A. AввоTT \& MCDEERMID, K. (eds.), Taxonomy of economic seaweeds with reference to some Pacific species, Vol. VIII. California Sea Grant College Program, La Jolla, California.

SANTElices, B. 2004: Parviphycus, a new genus in the Gelidiellaceae (Gelidiales, Rhodophyta). Cryptog., Algol. 25: 313-326.

SuÁREZ, A. M. 2005: Lista de las macroalgas marinas Cubanas. - Rev. Invest. Mar. 26: 93148.

TAYLOR, W. R. 1929: Notes on algae from the tropical Atlantic Ocean. - Am. J. Bot. 16: 621630.

TAYLOR, W. R. 1943: Marine algae from Haiti collected by H. H. Bartlett in 1941. - Pap. Mich. Acad. Sci., Arts \& Lett. 28: 143-163, pls. I-IV.

TAYLOR, W. R. 1960: Marine algae of the eastern tropical and subtropical coasts of the Americas. Ann Arbor, Michigan.

TAYLOR, W. R. 1969: Notes on the distribution of West Indian marine algae particularly in the Lesser Antilles. - Contr. Univ. Mich. Herb. 9: 125-203.

Address of the author:

Professor Michael J. Wynne, University of Michigan Herbarium, 3600 Varsity Drive, Ann Arbor, Michigan 48108, U.S.A.

E-mail: mwynne@umich.edu

FAX: +734-998-0038

Manuscript received: May 20 2010. 